\title{
Enterprise Risk Management and Performance of Selected Listed Consumer Goods Companies in Nigeria
}

\author{
Yinka M. Salaudeen ${ }^{1}$, Taibat A. Atoyebi ${ }^{1} \&$ Bamidele A. Oyegbile ${ }^{1}$ \\ ${ }^{1}$ Department of Accounting, Faculty of Management Sciences, University of Abuja, Nigeria \\ Correspondence: Taibat A. Atoyebi, Department of Accounting, Faculty of Management Sciences, University of Abuja, \\ FCT Abuja, Nigeria.
}

Received: January 8, 2018

Accepted: January 25, 2018

Available online: January 30, 2018

doi:10.11114/afa.v4i1.2918

URL: https://doi.org/10.11114/afa.v4i1.2918

\begin{abstract}
Enterprise Risk Management (ERM) is an integrated framework and monitoring tool for managing uncertainties surrounding the business objectives. This study evaluated the relationship between enterprise risk management and performance of Twenty (20) consumer goods companies listed on the Nigerian Stock Exchange. The independent variables used are existence of risk management committee, existence of financial expertise, existence of audit committee, existence of Chief risk officer and board size. The study adopted ex post facto research design and data were sourced from annual reports and accounts of the selected Consumer Goods Companies. The collated data were analysed using descriptive statistics and generalised least square. The results reveal that risk management committee, financial expertise and board size have significant positive effect on performance. The results also revealed that existence of audit committee has a significant negative effect on performance while existence of chief risk officer has no significant effect on performance. The study therefore recommended that the regulatory authorities and other relevant institutions are enjoined to reassess their supervisory role with the view to strengthen the ERM process and taking the issue of risk management seriously at every level of organisations to provide reasonable assurance.
\end{abstract}

Keywords: risk, enterprise risk management, performance, consumer goods companies

\section{Introduction}

The global economic conditions are continuously changing due to innovations, changing nature of business environment and risk drivers. This illustrates the realities that organizations are facing risks that threaten reputation and brand as scope of uncertainties broadened. The risks have become the most important factors that influence the goal of an enterprise (Liu, 2012). The goal of an enterprise is to improve performance; performance is the ability of the firm to generate earnings given the risky environment that the enterprise operates. Therefore, how to deal with risks and how to understand their nature has become companies' first priority. As it is widely acknowledged, companies are set up to create maximum value for their stakeholders, and all activities relating to wealth creation are exposed to risks, therefore, companies are constantly facing uncertainties. Risks are uncertainties which affect a company's ability to achieve its objectives and may result in many interdependent outcomes either negative or positive.

Some risks are necessarily encountered in order to take advantage of strategic opportunities and also, risks that impend success must be mitigated. Antonius (2015) posits that increased attention is being placed on the subject of risk management. Therefore, uncertainties have inevitably shifted organizations' attention towards a new paradigm from a "silo based perspective" to a more "holistically risk management": hence, the evolution of Enterprise Risk Management (Connair, 2013). The Nigeria business environment is examined to be unfriendly with reference to uncertainties in political regimes, cyber security risks, the demographic structure, the economic situation, falling oil prices and geopolitical conflicts. In view of this, management of companies cannot afford to manage risks casually, especially in this era of constantly changing innovation and technological developments.

Consequently, Enterprise Risk Management (ERM) is adopted as a strategic tool structured to help management to respond to impending risks and manage uncertainties using an integrated and all-inclusive approach. According to Ghazali and Norlida (2013), ERM is linked to corporate governance so that it can assist organizations to better understand, improve and assess risk in an appropriate manner. Recently, there has been an appreciable attention on ERM as a strategic tool for effective corporate governance. Nigerian government, through its capital market regulator 
introduced code of corporate governance where risk management was clearly stated and viewed as one of the principal responsibilities of management. Management is required to recognise principal risks of all aspects of the business, define their companies' risk policy, risk appetite, risk limits and form an opinion on the efficacy of the entire risk management process.

Management is responsible for the implementation and monitoring of risk management process and incorporating it into day to day activities of the company. This requirement on the best practices of the code is recommended by Nigeria code of corporate governance for all listed companies to disclose their risk appetite, risk exposure and disclosure of establishment of risk management committee in their annual reports. In addition, Committee of Sponsoring Organizations of the Treadway Commission (COSO, 2004) emphasized that implementation of ERM by companies largely depend on corporate governance, enabling laws, regulations, and listing requirements. According to Ishaya and Siti (2015), the implementation of ERM is usually influenced by existence of corporate internal audit effectiveness, existence of risk management committee, existence of chief legal officer, chief risk officer, firm size and regulatory support like, laws and other regulatory compliance.

\subsection{Statement of the Problem}

It is a common and acceptable knowledge that the global financial crisis has left a scar on global economy and the Nigerian economy is not an exception. While investors and shareholders need to be protected through regulation, it is also important for the issuers of securities they invest in, to adhere to effective risk management (OECD, 2011). For Nigeria to achieve a long-term economic growth, the country's faltering consumer sectors must be strengthened. The need to bolster the performance of this vital sector has become even more urgent after the National Bureau of Statistics (NBS) reported that Nigeria's GDP contracted by $0.36 \%$ in the first quarter of 2016 . The consumer goods sector has been one of the hardest hit sectors in the current economic downturn caused by unforeseen slump in global oil prices. In the report released by NSE, all the indexes at the Nigerian Stock Exchange (including the benchmark All Shares Index and consumer goods index) declined seriously in 2015.

It is also imperative to note that, the indexes that measure industrial production and consumer sectors declined in the $1^{\text {st }}$ and $2^{\text {nd }}$ Quarters of 2016. The trend analysis of NSE consumer goods index shows that average performance of the sector dropped by $24 \%$ in $2011,26.2 \%$ in $2012,13.7 \%$ in 2014 and $18.8 \%$ in 2015 .The sector is among the fastest growing businesses in Nigeria; however, volatility in oil prices and the changes in business models coupled with global economic crisis and consumer preferences have exposed consumer products and retail companies to business risk. In addition, the unpredictable business environment and globalization have also increased risks facing firms and consequently leading to dwindling financial performance of companies in the Consumer Goods sector of Nigerian economy.

Despite aforementioned factors, little attention is given to Risk management coupled with weak and ineffective risk management. Therefore, in order to avoid earnings volatility and return Nigeria to the path of long-term economic growth, stimulating the consumer goods sector through the use of enterprise risk management model that mitigate impending risk in consumer goods sector is emphasized. Accordingly, based on the data acquired from the annual reports and accounts of consumer goods industry, it indicated that many of the companies have Risk Management Committee (RMC), Audit Committee, Chief Risk Officer (CRO), executive directors with financial expertise and acceptable board of directors which are variables that will implement ERM framework. Therefore, the primary purpose of this study is to determine the type of relationship that exists between ERM and firm performance in consumer goods industry. To achieve these, the study formulated the following hypotheses

$\mathrm{H}_{01} \quad$ Risk Management Committee does not have a significant effect on performance of a consumer goods company.

$\mathrm{H}_{02}$ The number of financial experts on the board does not have a significant relationship with performance of consumer goods companies.

$\mathrm{H}_{03}$ Audit committee does not have a significant relationship with performance of consumer goods companies.

$\mathrm{H}_{04}$ The existence of Chief Risk Officer does not has a significant relationship with firm performance.

$\mathrm{H}_{05} \quad$ Board size does not significantly affect performance of a consumer goods company.

\section{Material Studied}

\subsection{The Concept of Risk and Enterprise Risk Management (ERM)}

Every step taken in life involves risk; Life itself is a risk. Risk occurs in the everyday life of humans, as well as companies. Consequently, it is imperative to detect and manage risks in order to lessen their threats and improve their potential (Reuvid, 2012). Risk is the likelihood of gaining or losing something important. It is the implication of action taken in the face of possibility or threat of damage that is caused by external or internal weaknesses which may be avoided through pre-emptive action. Sobel and Reding, (2004) view risks as that unknown or unforeseen circumstances 
that may stand in the way to success. Risks are uncertainty that can affect a company's ability to attain its objectives and can lead to many interdependent results, so business risk is related to business objective; therefore, risk taking is a necessity for success; there is no reward devoid of risk.

The awareness of ERM was very low not until when Committee of Sponsoring Organization of Treadway Commission (COSO) initiated ERM Framework in 2001 by engaging PriceWaterhousecoopers (Pwc) to develop a comprehensive ERM framework for management and to improve organization risk management. COSO is a joint initiative to combat corporate fraud established by five private organizations in United States. Their objective is to guide executive management and governance entities on important aspects of corporate governance, internal control, ERM, and fraud. Hoyt and Liebenberg (2008) affirmed that, the result of Pwc effort was formally announced in 2004. Gates, Nicolas, and Walker (2012) asserted that COSO ERM framework components help companies to cope with risk and provide reasonable guarantee about attaining firms' objectives. They also confirmed that components are internal environment, objective setting, event identification, risk assessment, risk response, control activities, information communication and monitoring. ERM provides framework for Board of directors and management to deal effectively with uncertainties, the risk and opportunities associated with firm objectives. ERM builds on internal control and provides a more vigorous and all-encompassing focus on risk management.

ERM is a strategic issue for businesses and the academia which is now broader in scope and have been included in corporate philosophy (Kleffner, Lee, \& McGannon 2003). In Carrying out ERM, COSO emphasizes the existence of ERM framework such as Objective setting, risk identification, Risk assessment, Risk response, internal control environment, involvement of management, divisions, and all line of directors within an organization (Arif, 2011). In addition, (COSO, 2004) emphasized that the implementation of ERM by companies largely depend on corporate governance, enabling laws, regulations, and listing standards. Therefore, the implementation of ERM framework is usually effected by existence of audit committee, risk management committee, chief legal officer, chief risk officer, regulations like, laws and other regulatory compliance and the size of the firm (Ishaya \& Siti, 2015).

\subsection{Enterprise Risk Management (ERM) and Performance}

Shima, Mahmood, Happy and Akbar (2013) examined the relationship between enterprise risk management and firm performance using 175 listed non-financial public companies in Malaysia. Data were sourced from annual report and accounts of the listed companies using existence of risk management committee, finance experts, board size, Audit committee and separation of audit committee and risk management as independent variables while Return on Assets is proxy for performance. Their study used multiple regressions to test the relationship and the findings show that there exists a significant relationship between ERM and firm performance. Ahmad and Tahir (2011) examined the impact of ERM on firm performance using 528 public listed companies in Malaysia. The study used OLS regression analysis on one year financial data of the companies sourced from Osiris Database. The findings of their study revealed that ERM has a significant positive relationship with firm performance. Kallamu (2015) also examined the impact of risk management committee attributes and firm performance of 37 Malaysian finance companies covering period of five years from 2007 financial year to 2011 using finance expertise, presence of none executive directors, existence of risk management committee as independent variables and return on assets as dependent variable. The result indicated a significant positive relationship between risk management committee and firm performance.

Kacem and ZemZem (2014) studied the relationship between risk management, corporate governance and performance in 17 Tunisian lending institutions over a period of 10years using OLS regression. Their findings revealed that board size has a significant effect on performance while the existence of a risk committee within the institution has a significant negative effect on performance. Kittipat and Nopadol (2014) examined enterprise risk management system (ERMS) and financial performance of listed companies on Thailand Stock Exchange. The study used primary data obtained from questionnaires administered to management of the sampled companies. The results of the study indicated that ERMS has a weak positive correlation with financial performance as measured by ROA, ROE and EPS. Arif (2011) investigated the effect of ERM to company's financial performance after its implementation using 18 non-banks listed public companies in Indonesia. The study uses existence of chief risk officer and existence of risk management committee as independent variables while earnings per share and return on assets were used as dependent variables. The result of statistical test after implementing ERM indicate that financial performance only significant below 5\% and the $t$ value is greater than $t$ table. This explained that after ERM implementation, it gives significant difference to income volatility. In a similar study, Ugwuanyi and Ibe (2012) examine ERM and firm performance of Nigerian Brewery industry using cross section survey design. The questionnaires were distributed to top and middle management staff of 3 major brewing firms in Nigeria. The results of the statistical test indicate that ERM enhances the performance of firms in the Brewery industry in Nigeria.

In another research on ERM and firm performance, Pagach and Warr (2010) also examined 106 sample firms that adopt ERM and they discovered a reduction in earnings volatility in some firms that adopted ERM. However, their overall 
results shows that enterprise risk management does not creating value. They affirm that ERM may be working very effectively, but observable financial measures are unaffected. Ping and Muthuveloo (2015) studied the effect of implementing ERM on firm performance using both primary and secondary data. Their results revealed that implementation of ERM has a significant influence on firm performance.

Silva and Chan (2014) carried out research on ERM adoption and firm performance in 30 companies listed on Brazilian stock exchange for a period of 9 years. The findings show a positive and significant relationship between ERM and firm performance. Liebenberg and Hoyt (2003) posited that there is no significant difference between firms that by appointing a CRO and other firms of a similar size and industry affiliation. Hoyt and Liebenberg (2008) indicated that implementing ERM can affect the level of market to book ratio. However, Beasley, Pagach and Warr, (2008) indicate that there is a decrease in company's income volatility after implementing ERM. Their finding is in line with the main purpose of ERM which is to reduce the income volatility and avoid the bankruptcy to occur. Odonkor, Osei, Abor and Adjasi (2011) examined 18 Ghanaian banks and they discovered that high involvement of boards in the risk management process have a significant impact on the efficient risk management system, and this customarily leads to considerably higher ERM practices in the banks. In the same vein, Njogo (2012) conducted research in risk management practices in the Nigerian banking sector and opines that high level of leverage is related to high risk. Thus, the banks need to implement a more rigorous and effective ERM.

In identifying whether the company implement ERM or not, there are several variables that can be found in annual reports and accounts of listed companies. Therefore, based on review of related literature, five independent variables were selected which are relevant to the study such as Existence of Risk Management Committee, the Existence of Financial Expertise, the existence of Chief Risk Officer (CRO), Existence of Audit Committee and Board Size. The study of Kacem and Zemzem (2014) revealed that the existence of a risk management committee in the institution has a significant negative effect on performance. Fadun (2013) maintained that risk management committee has a significant influence on performance. Liebenberg and Hoyt (2003) affirmed that appointing CRO is a sign that a company implements ERM. Wan, Ahmed and Mohammed (2010) investigated the adoption level of ERM in Malaysia and their study discover that a positive relationship between the presence of CRO and firm value. The findings of a study conducted by Daud, Yazid, and Hussein (2010) on the effect of Chief Risk Officer on Enterprise Risk Management Practices indicated that CRO and ERM were significant and CRO is an important factor in risk management.

The professional experience of board members has become very significant and germane to the performance of an organisation (Rose \& Rose, 2008). Xie, Davidson, and DaDalt (2003) affirmed that if directors do not have ample knowledge of accounting, then it will diminish their ability to create informed decisions and may lead to higher cost of agency. However, Van Ness, Miesing and Kang (2010) examined board of directors' composition and corporate performance and discovered a negative relationship between board expertise and firm performance. Existence of audit committee plays a role in ERM because it ensures oversight of internal processes and enhances continuous improvement in the organization (Badara \& Saidin, 2014). Hasnah and Adejoh (2015) affirm that there is significant relationship between audit committee and firm performance. There are different views on whether board size has impact on firm performance. Kyereboah-Colemon (2007) indicated that large boards enhance shareholders wealth more positively than smaller ones.

\section{Area Description}

The study adopted ex-post facto research design. This study adopted ex-post facto because it allows the pre-existing independence variables prior to the study to be held constant and serve as control group for the stated hypotheses. The firm performance of each selected Consumer Goods Industry for six years form dependent variable while risk management committee, audit committee, risk officers, financial expertise and board size are the independent variables.

The population for the study is Twenty Five (25) Consumer Goods Companies, quoted on Nigeria stock exchange, therefore the population size is 25 . Base on review of related literature, this study identified 5 (Five) independent variables suitable for the study. The variables are Risk Management Committee, Audit Committee, Number of Financial Experts, Board Size and Chief Risk Officer. For a company to be selected as a sample, it must have at least 4 (Four) of these variables in the annual reports. The critical look at the annual reports of all the listed consumer goods Companies indicated that only twenty companies met the requirements for selection. Hence the sample size is Twenty (20). The data for this study are secondary data sourced from annual reports and accounts of the Twenty (20) sampled companies covering a period of 6 years starting from 2010 to 2015.

The model in the study is structured using generalized regression analysis. The model has explanatory variables namely Risk Management Committee, Financial Expertise, Existence of Chief Risk Officer, Audit Committee, and Board Size. Performance (ROA) represents dependent variable. The study uses Return on Assets (ROA) as a performance yardstick because it shows how companies are able to generate revenue from the investment of assets. ROA takes into consideration total assets of the companies either earning or nonearning assets, and takes into account both equity and 
debt unlike ROE. Based on this, Shima, Mahmood, Happy, Musriyama and Akbar (2013) model is adapted for this work. The mathematical and conceptual framework is expressed below:

$$
\mathrm{PERF}_{i t}=\beta_{0}+\beta_{1} \mathrm{RMC}_{i t}+\beta_{2} \mathrm{FIN}_{\mathrm{EXP}}+\beta_{3} \mathrm{CRO}_{i t}+\beta_{4} \mathrm{ACOM}_{i t}+\beta_{5} \mathrm{BSIZE}_{i t}+\mathrm{e}_{i t}
$$

Where:

PERF $=$ Firm performance

$\beta_{0}=$ constant

$\beta_{1-5}=$ is coefficient of the explanatory variable

$\mathrm{RMC}=$ Risk management committee

FIN.EXP $=$ Financial expertise

$\mathrm{CRO}=$ Existence of chief risk officer

$\mathrm{ACOM}=$ Audit committee

BSIZE $=$ Board size $)$

eit $=$ error term

Table 1. Measurement of Variables

\begin{tabular}{|c|c|c|}
\hline Variables & Measurement & Author \\
\hline PERF $=$ Performance & $\begin{array}{l}\text { Profit after tax divided by total Assets of the } \\
\text { company (Return on Assets) }\end{array}$ & $\begin{array}{l}\text { Haniffa and Hudaib (2006), O"Connell and } \\
\text { Cramer (2010)Kamardin and Haron } \\
(2011) \text {,. }\end{array}$ \\
\hline $\mathrm{RMC}=$ & Proxy as 1 for presence and 0 otherwise for & Hoyt and Liebenberg (2011) \\
\hline Risk Management & risk & \\
\hline Committee & management committee & \\
\hline FIN.EXP = Financial & Percentage of directors with & Carpenter and Westphal (2001) \\
\hline Expertise & $\begin{array}{l}\text { accounting/finance background or relevant } \\
\text { professional qualification }\end{array}$ & \\
\hline $\mathrm{CRO}=$ Chief Risk Officer & Proxy as 1 for presence and 0 otherwise & Liebenberg and Hoyt (2003) \\
\hline $\mathrm{ACOM}=$ Audit committee & Size of audit committee on the board & Karamanou and Vafeas (2005) \\
\hline BSIZE $=$ Board size & Number of director on the board & O"Connell and Cramer (2010). \\
\hline
\end{tabular}

Source: Researcher's Review 2017

Table 1 shows how the variables in equation 1 are measured in this study.

\section{Methods}

Descriptive statistics such as: mean, median and standard deviation were used to describe the data. Normality test, Heteroscedasticity and Variance Inflation Factor (VIF) test are conducted for reliability of regression results. A generalized regression analysis is used to explain the impact of enterprise risk management on firm performance. GLS is considered because it gives maximum and more reliable estimates. The result is expected to reveal the relationship between ERM and firm performance.

\section{Results}

Table 2. Descriptive Statistics

\begin{tabular}{lllllll}
\hline & *RMC & *FIN.EXP & *CRO & *AUD. COM & *BSIZE & *PERF \\
\hline MEAN & 0.95 & 0.4056 & 0.275 & 6 & 9.9 & 0.07845 \\
MEDIAN & 1 & 0.4 & 1 & 7 & 9 & 0.08 \\
MAX. & 1 & 0.75 & 1 & 7 & 17 & 0.4 \\
MIN. & 0 & 0.25 & 0 & 4 & 6 & -0.24 \\
STD.DEV & 0.219043 & 0.103947 & 0.451261 & 0.64345971 & 3.006726 & 0.1216902 \\
Observations & 120 & 120 & 120 & 120 & 120 & 120 \\
\hline
\end{tabular}

Source: STATA 13 Output, 2017.

$* R M C=$ Risk Management Committee, *FIN.EXP=Financial Expertise, *ECRO=Existence of Chief Risk Officer, *AUD. COMM $=$ Audit Committee, ${ }^{*} B S I Z E=$ Board Size, $* R O A=$ Return on Asset .

Table 2 provides basic descriptive statistics of the variables. Return on assets shows a mean value of $7.8 \%$. This is not too different from Shima et al (2013) finding of 7.68 mean value. 95\% of companies have risk management committee while 5\% do not have risk management committee? However, this might due to the fact that risk management committee is does not exist in some companies in the early years of the period under investigation. Adoption of this 
variable may serve as long term competitive advantage to companies. Nigerian government, through its capital market regulator introduced code of corporate governance where the establishment of risk management committee was recommended. The presence of financial expertise, measured by the percentage of directors with accounting/finance background or relevant professional qualification, shows mean value of $40.5 \%$. This is an indication that $59.5 \%$ of board members do not have background in accounting/finance. The minimum percentage of directors with background in accounting/finance is $25 \%$ and maximum is $75 \%$.

The table also shows that on the average $27 \%$ of the sample companies have chief risk officer while $73 \%$ do not have. The mean value for audit committee reflects 6 . This implies that audit committee of sample companies have significant members and complied with provisions of section 359 (4) of companies and allied matter acts that stipulates 3 shareholders and 3 directors respectively. Thus, this may affect the effectiveness of audit committee and brings about greater board's attention and governance oversight, which in turn increase shareholders wealth. Board size of the sample companies have an average of 9.8 which can be approximated to 10 and this shows level of compliance with the Securities and Exchange Commission code of corporate governance. The NSE code recommends for companies to have a minimum of 5 board members. It therefore means that the sample companies have an average of 10 which is more than minimum requirement. Furthermore, the minimum number of board size is 6 with maximum of 17 directors.

\subsection{Diagnostic Tests}

The absence of multicollinearity is established when the value of variance inflation (VIF) factor is greater than 1 and below the benchmark of 10 . To determine the absence of multicollinearity, test for collinearity is therefore performed using VIF.

Table 3. Results of the Variance Inflation Factor Test

\begin{tabular}{llll}
\hline Variables & Observations & Coefficient & VIF \\
\hline & 120 & Variance & \\
RMC & 120 & 0.455620 & 2.19 \\
AUD. COMM & 120 & 0.424818 & 2.35 \\
BSIZE & 120 & 0.912201 & 1.10 \\
FINEXP & 120 & 0.913898 & 1.09 \\
CRO & 120 & 0.900613 & 1.11 \\
Mean VIF & 0.000639 & 1.57 \\
\hline
\end{tabular}

Source: STATA 13 Output, 2017

The result of the variance inflation factor as shown in Table 3 that all the explanatory variables are relevant to the study, with value greater than minimum possible value of variance inflation factor (VIF) 1 and below the benchmark of 10, which is indicative of the absence of multicollinearity. This shows that all the variables are appropriate and fit well into the model.

\subsubsection{Test for Multicollinearity}

In order to examine the linear relationship between variables, the test for multicollinearity is hereby carried out. The essence of carrying out multicollinearity test is to avoid misleading regression result.

Table 4. Correlation Matrix

\begin{tabular}{lllllll}
\hline & PERF & RMC & FINEXP & ECRO & AUDCOM & BSIZE \\
\hline PERF & 1 & & & & & \\
RMC & 0.2779 & 1 & & & & \\
FINEXP & 0.3814 & 0.1691 & 1 & & & \\
ECRO & 0.0236 & 0.1413 & -0.1031 & 1 & 1 & \\
AUDCOM & 0.1790 & 0.7211 & 0.0438 & 0.2841 & 0.2011 & 1 \\
BSIZE & 0.2658 & 0.0658 & 0.1941 & 0.0666 & & \\
\hline
\end{tabular}

Source: STATA 13 Output, 2017

As shown in Table 4 that there is no incidence of multicollinearity between the independent variables. The degree of correlation between risk management committee and performance is 0.277 (positively low correlated) and significant, which implies that as risk management committee increases, return on asset increases and vice versa. The degree of correlation between board size and risk management committee is 0.06 (positively low) which implies that as board size increases risk management committee increases and vice versa. Existence of chief risk officer is negatively associated with performance. The coefficient between audit committee and existence of chief risk officer is 0.28 (positively correlated) which means they both move in same direction. The coefficient of correlation between financial expertise and return on assets is 0.38 (positively correlated) that is, they move in the same direction. This certifies that the independent variables are fit to be estimated together on the same regression model. The correlation result also shows 
the relationship between the performance and Enterprise Risk Management proxies.

5.1.2 Normality Test

Table 5. Result of Normality Test

\begin{tabular}{llllll}
\hline Variables & Obs & $\mathrm{W}$ & $\mathrm{V}$ & $\mathrm{Z}$ & Prob>z \\
\hline ROA & 120 & 0.98714 & 1.237 & 0.477 & 0.03166 \\
RMC & 120 & 0.71071 & 27.838 & 7.452 & 0.00000 \\
FINEXP & 120 & 0.84596 & 14.823 & 6.041 & 0.00000 \\
ECRO & 120 & 0.97516 & 2.390 & 1.952 & 0.02547 \\
AUDCOM & 120 & 0.94147 & 5.632 & 3.873 & 0.00005 \\
BSIZE & 120 & 0.95547 & 4.285 & 3.260 & 0.00056 \\
\hline
\end{tabular}

Source: STATA 13 output, 2017

Table 5 shows that all the variables are normally distributed simply because the probability value is significant. Therefore, the null hypothesis is rejected.

Table 6. Result of Regression Analysis

\begin{tabular}{ll}
\hline Summary of the Result & \\
No of observation & 120 \\
F. Statistic & $9.93^{* * * *}$ \\
R. squared & 0.3034 \\
Adj. R- squared & 0.2728 \\
\hline
\end{tabular}

Source: STATA 13 output, 2017

The coefficient of multiple determinations in Table 6 shows the explanatory power of the independent variables to be $30 \%$ with adjusted R-square showing $27 \%$. This means that, about $27 \%$ of the variation in Performance is accounted for by the ERM variables. The F-statistics is significant which indicates the fitness of the model.

Table 7. Regression Results

\begin{tabular}{lllllll}
\hline Variables & Coef. & Std. Err & $\mathrm{T}$ & $\mathrm{p}>|\mathrm{t}|$ & $95 \%$ Conf. & Interval \\
\hline RMC & .1408891 & .0643924 & 2.19 & 0.031 & 0.133283 & .26845 \\
FINEXP & .489084 & .0965518 & 5.07 & 0.000 & .2978157 & .6803523 \\
ECRO & .00986 & .0223552 & 0.44 & 0.660 & -.0344255 & .0541454 \\
AUDCOM & -.0193514 & .0227463 & -2.85 & 0.007 & .0644117 & .0257088 \\
BSIZE & .0140783 & .0033144 & 4.25 & 0.000 & .0075125 & .0206442 \\
Const & -.2790304 & .1071501 & -2.60 & 0.10 & -.491294 & -.0667668 \\
\hline
\end{tabular}

Source: STATA 13 output, 2017

\section{Discussion}

The finding shows that, the implementation of enterprise risk management could enhance the performance of firms in the consumer goods sector of the Nigerian economy. The implication of this finding is that, the proper implementation of this model to managing all the risks of the organization could enhance the extent to which the organizational objectives are achieved and promises made to the stakeholders are fulfilled. Table 7 shows that risk management committee has a significant positive effect on firm performance at $5 \%$ level of significance. The relationship between the number of finance experts and firm performance is positive and significant at $1 \%$ level of significance. Table 7 also shows that the existence of chief risk officer has a coefficient of 0.00986 which depicts a weak positive insignificant relationship with performance. The regression result as shown in table 7 indicates that the size of audit committee is significantly negatively related to performance at $1 \%$ significant level while board size significantly positively affects firm performance at $5 \%$ level of significance.

\section{Conclusion}

Management is responsible for executing and monitoring the process of risk management and incorporating it into the daily activities of the company. Therefore the significant correlation between ERM and firm performance suggests that ERM can leverage firm performance by ensuring that adequate resources are deployed to enhance risk management systems. The existence of risk management committee, financial expertise on the board, size of audit committee, and board size have significant impact while existence of chief risk officer exhibits insignificant impact on performance. The study shows that there exist a significant positive relationship between risk management committee and firm performance. This means that when an organization has a risk management committee in place, the organization can use it as a competitive advantage to transform risk management into a value-enhancing capability. This supports the findings of Hoyt and Liebenberg (2008), Shima et al (2013) and Kallamu (2015). On the other hand, the finding is partially in accordance with the findings of Kacem and Zemzem (2014), whose findings indicate a negative but 
significant effect of existence of risk management committee on performance. Board size has a positive significant impact on firm performance and this finding is consistent with the findings of Kyereboah-Colemon (2007) and Kacem \& ZemZem (2014). This means that large boards enhance shareholders wealth more positively than smaller ones and also implies that the NSE code recommendation for companies to have a minimum of 5 board members is in order.

The findings of the study also revealed that the existence of finance experts has a significant positive impact on firm performance. This will enhance firm performance and attainment of organization's objectives. However, the positive relationship is contrary to prior studies such as Kallamu (2015) and Shima et al (2013) whose findings were negative. The existence of chief risk officer has an insignificant impact on performance of consumer goods companies. This is contrary to the findings of Daud, Yazid and Hussein (2010). The size of audit committee has a negative significant impact on performance of the consumer goods companies. However, these companies have complied with the provisions of section 359(4) of Companies and Allied Matter Acts (CAMA) that stipulated 3 shareholders and 3 directors respectively. This implies that the requirements of CAMA is quite adequate. The existence of risk committee, chief risk officer, finance experts, audit committee, acceptable board size, and development of policies on ERM and effective coordination of firms' activities will go a long way in building risk management capabilities.

\section{References}

Ahmad, R. R., \& Tahir, M. T. (2011). Review of the literature on enterprise risk management. Business Management Dynamics, 1(5), 8-16.

Antonius, A. (2015). The essential of enterprise risk management. Indonesia institute of commissioners and director. Retrieved August 11, 2016 from: www.ikdi.org/cms/wp-contents/englishversion.

Arif, S. (2011). The analysis of company's financial performance before and after implementing ERM: An empirical study in Indonesia. Asian Journal of Business and Management Sciences, 17(1), 92-105.

Badara, M. A. S., \& Saidin, S. Z. (2014). Emperical evidence of antecedents internal effectiveness from Nigerian perspective. Middle-East Journal of Scientific Research, 19(4), 460-469.

Beasley, M. S., Pagach, D., \& Warr, R. (2008). Information conveyed in hiring announcement of senior executives overseeing enterprise-wide risk management processes. Journal of Accounting, Auditing and Finance, 23(3), 311332. https://doi.org/10.1177/0148558X0802300303

Carpenter, M., \& Westphal, J. (2001). Boards of directors and firm performance: integrating agency. Academy of Management, 63(44), 639-663. https://doi.org/10.2307/3069408

Connair, S. (2013). Enterprise risk management: from silo to strategic objectives. Armed Forces Comptroller, 58(1), 24-26. Retrieved from http://search.ebcohost.com/login.aspx?direct=true.

COSO. (2004). Enterprise risk management—integrated framework executive summary. Retrieved April 23, 2016, from http:www.coso.org/Publications.

Daud, W. W., Yazid, A. S., \& Hussin, M. R. (2010). The effect of chief risk officer on enterprise risk management practices: evidence from Malaysia. International business and Economics Research Journal (IBER), 9(11), 233-271. https://doi.org/10.19030/iber.v9i11.30

Fadun, O. S. (2013). Risk management and risk management failure: Lessons for business enterprises. International Journal of Academic Research in Business \& Social Sciences, 3(2), 225-239.

Gates, S., Nicolas, J. L., \& Walker, P. L. (2012). Enterprise risk management: a process for enhanced management and improved performance. Management Accounting Quarterly, 13(3), 28-39.

Ghazali, Z., \& Norlida, A. M. (2013). Enterprise risk management and value creation: Initial findings amongst non-fianacial public listed companies in Malaysia bourse: Asia Economic and Financial Review, 3(7), 913-922.

Haniffa, R., \& Hudaib, M. (2006). Corporate governance structure and performance of Malaysia listed companies. Journal of Business Finance and Accounting, 33(7), 1034-1062. https://doi.org/10.1111/j.1468-5957.2006.00594.x

Hasnah, K., \& Adejoh, E. (2015). The impact of audit committee on firm performance. Mediterranean Journal of Social Sciences, 6(3), 34-43.

Hoyt, R. E., \& Liebenberg, A. P. (2011). The value of enterprise risk management. Journal of Risk and Insurance, 78(4), 795-822. https://doi.org/10.1111/j.1539-6975.2011.01413.x

Hoyt, R. E., \& Liebenberg, A. P. (2008). The value of enterprise risk management: evidence from the U.S. insurance industry. Journal of Risk and Insurance, 12(1), 175-188. 
Ishaya, J. D., \& Siti, Z. S. (2015). Determinants influencing the implementation of enterprise risk management in the Nigerian banking sector: International Journal of Asian Social Science, 5(12), 740-754. https://doi.org/10.18488/journal.1/2015.5.12/1.12.740.754

Kacem, O., \& Zemzem, A. (2014). Risk management, board characteristics and performance in Tunisian lending institutions. International Journal of Finance and Banking Studies, 3(1), 2147-4486.

Kallamu, B. S. (2015). Risk management committee attributes and firm performance. Journal of International Finance and Banking, 2(2), 1-24. https://doi.org/10.5296/ifb.v2i2.8580

Kamardin, H., \& Haron, H. (2011). Internal corporate governance and board performance in monitoring roles: Evidence from Malaysia. Journal of Financial Reporting \& Accounting 9(2), 119-140. https://doi.org/10.1108/19852511111173095

Karamanou, I., \& Vafeas, N. (2005). The association between corporate boards, audit committee and management earnings forecast. An empirical analysis. Journal of Accounting Research, 43(3), 453-486. https://doi.org/10.1111/j.1475-679X.2005.00177.x

Kittipat, L., \& Nopadol, R. (2014). Relationship between a successful enterprise risk management, a performance measurement system and the financial performance of Thailand listed companies. Journal of Applied Business and Economics, 16(2), 81-92.

Kleffner, A., Lee, R., \& McGannon, B. (2003). The effect of corporate governance on the use of enterprise risk management: Evidence from Canada. Risk Management and Insurance Review, 6(1), 53-73. https://doi.org/10.1111/1098-1616.00020

Kyereboah, C. A. (2007). Corporate governance and shareholder value maximization: an African perspective. African Development Review, 19(2), 350-367. https://doi.org/10.1111/j.1467-8268.2007.00165.x

Liebenberg, A. P., \& Hoyt, R. E. (2003). The determinants of enterprise risk management: evidence from the appointment of chief risk officers. Risk Management and Insurance Review, 6(1), 37-52 https://doi.org/10.1111/1098-1616.00019

Liu, J. (2012). The enterprise risk management and the risk oriented internal audit. International Business Journal, 10(4), 287-292. https://doi.org/10.4236/ib.2012.43036

Njogo, B. O. (2012). Risk management in the Nigerian banking industry. Kuwait Chapter of Arabian Journal of Business and Management Review, 1(10), 100-109.

O' Connel, V., \& Cramer, N. (2010). The relationship between firm performance and board characteristics in Ireland. European Management Journal, 28(5), 387-399. https://doi.org/10.1016/j.emj.2009.11.002

Odonkor, T. A., Osei, K. A., Abor, J., \& Adjasi, C. K. (2011). Bank risk and performance in Ghana. International Journal of Financial Services Management, 5(2), 107-120. https://doi.org/10.1504/IJFSM.2011.041919

OECD, (2011). Principles of corporate governance and its assessment methodology. Retrieved April 27, 2016 from:www.oecd.org/investment/pftitoolkit.

Pagach, D., \& Warr, R. (2011). The characteristics of firms that hire chief risk officers. Journal of Risk and Insurance, 78(1), 185-211. https://doi.org/10.1111/j.1539-6975.2010.01378.x

Ping, T., \& Muthuveloo, D. (2015). The impact of ERM on firm performance. Asian Social Studies Journal, 11(22), 149-159.

Reuvid, J. (2012). Managing business risk: A practical guide to protecting your business. Annals of Actuarial Science, 7(1), 155-157.

Rose, A. M., \& Rose, J. M. (2008). Management attempts to avoid accounting disclosure oversight: The effects of trust and knowledge on corporate directors' governance ability. Journal of Business Ethics, 83(2), 193-205. https://doi.org/10.1007/s10551-007-9611-1

Sobel, P. J., \& Reding, K. F. (2004). Aligning corporate government with enterprise risk management. Management Accounting Quarterly, 21(5), 1-9.

Shima, N., Mahmood, Z., Happy, A., \& Akbar, A. (2013). Enterprise risk management and performance in Malaysia. Interdisciplinary Journal of contemporary Research in Business, 5(1), 670-707.

Silva, J. B., \& Chan, B. L. (2014). Enterprise risk management and firm performance: evidence from Brazil. Retrieved March 3, 2017 from www.soac.unb.br/index.php/paper 
Skipper, H. D., \& Kwon, W. (2007). Risk management and insurance: Perspectives in a global Economy. Asia-Pacific Journal of Risk and Insurance, 2(2), 103-114.

Ugwuanyi, U. B., \& Ibe, I. G. (2012). Enterprise risk management and performance of Nigeria's brewery industry. Developing Country Studies, 2(10), 60-67.

Van Ness, R. K., Miesing, P., \& Kang, J. (2010). Board of director composition and financial performance in a Sarbanes-Oxley. Academy of Business and economics Journal,10(5), 56-74.

Wan, N. D., Ahmad, S., \& Mohdammad, R. H. (2010). The effect of chief risk officer on enterprise risk management practices: evidence from Malaysia. International Business \& Economics Research Journal, 9(11), 55- 64

Xie, B., Davidson, W. N., \& Dadalt, P. J. (2003). Earnings management and corporate performance: the role of board and the audit committee. Journal of Corporate Finance, 9(3), 295-316. https://doi.org/10.1016/S0929-1199(02)00006-8

\section{Copyrights}

Copyright for this article is retained by the author(s), with first publication rights granted to the journal.

This is an open-access article distributed under the terms and conditions of the Creative Commons Attribution license which permits unrestricted use, distribution, and reproduction in any medium, provided the original work is properly cited. 